\title{
The Invisible Barrier to Integrating Computer Technology in Education
}

\author{
Ester Aflalo ${ }^{1}$ \\ ${ }^{1}$ Hemdat Hadarom Academic College of Education, Netivot, Israel \\ Correspondence: Ester Aflalo, Hemdat Hadarom Academic College of Education, P.O.B. 412, Netivot 80200, \\ Israel. Tel: 972-8-993-7668. E-mail: esteraf@macam.ac.il
}

Received: January 20, 2014

Accepted: March 20, 2014 Online Published: May 14, 2014

doi:10.5539/jel.v3n2p120

URL: http://dx.doi.org/10.5539/jel.v3n2p120

\begin{abstract}
The article explores contradictions in teachers' perceptions regarding the place of computer technologies in education. The research population included 47 teachers who have incorporated computers in the classroom for several years. The teachers expressed positive attitudes regarding the decisive importance of computer technologies in furthering teaching, learning and their professional advance. However they mainly incorporated basic computer applications in their teaching, and hardly utilized computer mediated communication. It was further found that most teachers are convinced that meaningful learning can be attained without the need for computer technology. This position, together with the partial use of these technologies, exposes a rooted attitude according to which the teachers do not believe in the pedagogic advantages of computer technologies. The contradictions in their perceptions inhibit the process of change in attitude needed for the full assimilation of computer technologies in education.
\end{abstract}

Keywords: teachers' perceptions, information and communication in education, computer integration, changes in education

\section{Introduction}

More than three decades have passed since the entry of computers to school. Nowadays, new information and communications technologies (ICT) are perceived by educational policy makers as a lever for the new and dynamic pedagogy, which offers other ways of improving teaching and learning (Mouza, 2003; Wellington, 2005). Solomon (1996) emphasizes that realizing the constructivist approach in education is feasible thanks, to a large extent, to computerization and its potential.

Although agreement is lacking over the level of impact of these technologies on altering the face of education (Cuban, 2001), there would seem to be agreement over their necessity. Nowadays the discussion focuses on the question of the conditions for their assimilation in the education system and on examining the factors involved in that process.

Despite the headway in the practice of integrating computers in education significant disparity still exists between the promise embedded in the ICT revolution and the reality in schools. Studies verify that many students and teachers confirm that there has indeed been an increase in the use of computers in the classrooms thanks to their greater accessibility, to the teacher training, and to policy that encourages their use, but this is mainly manifested in basic actions - the use of a word processor for writing, for constructing presentations, for seeking information on the network and for emailing (Cuban, 2001). The extent to which computer technologies are integrated in the education system using more advanced techniques - problem solving using ICT, the use of computerized laboratories, managing a class internet site, learning in cooperative communities and so on - was lower than expected (Palak \& Walls, 2009; Hills, 2010).

Why is the situation thus? Why was the pedagogic potential embedded in the computer technologies not realized in full? According to Ertmer (2005) many teachers use advanced technology to further their traditional methods without altering their pedagogic approach and without striving to realize new objectives. It is not surprising, therefore, that the partial integration of computer technologies by teachers, and the use of basic methods is far more common than their integration using advanced methods - methods that are likely to alter the teaching from its foundations. Rogers (2003) maintains that the adoption of innovation is a multi-stage process: the pace at the start of the process is slow, then accelerates dramatically, peaks, and thereafter slows again. Since the use of basic applications preceded the use of advanced applications, it is possible that insufficient time has passed for 
the acceptance of the desired educational changes (Ertmer, 2005). Several researchers developed models for integrating technology in the education system (Becker, 1994; Franklin, 2007; Sandholtz, Ringstaff \& Dwyer, 1997) according to whom teachers need five-six years in order to make educated use of technologies in a manner that will advance the realization of the constructivist approach. If these models are indeed correct, the question is, why, after more than thirty years since the introduction of computers to the education system, is their educated use is so partial? The significant assimilation of computer technologies in the education system would seem to depend on many and complex factors, and on coping with impediments that are still not fully understood.

\section{Factors Affecting the Integration of Computer Technology in Education}

Integrating computer technologies in the education system is likely to have broad implications on diverse areas school life, the organization of time and space, the students' role, the role of the teachers and the curriculum. The many factors that affect the integration of computer technologies in the education system, and the reasons for difficulties in integration, can be divided into two general categories: the one - organizational and administrative factors such as adapting the infrastructures and peripheral equipment, its quality and its availability (Venezky \& Davis, 2002; Pelgrum, 2001), technical and pedagogic support (Pelgrum \& Anderson, 1999) and so on, and the second category - factors that are associated directly with teachers.

\subsection{Factors Associated Directly with Teachers}

A key factor that affects the integration of computer technologies in school is the teachers' training, which is an essential condition for introducing change and innovation in school. This does not only imply the teachers' skill in using technological tools, but skill that emphasizes the educational rationale, since the main problem regarding computer applications in education would seem to be more pedagogic than technological. The importance of the training lies in altering the traditional perception of teaching to a constructivist perception, i.e. in preparation towards change in the teachers' roles and prior to focusing on new ways to manage learning (Kay, 2006; Pelgrum \& Anderson, 1999). Teachers who adopted the pure constructivist approach tended to integrate the technology in more advanced ways than those who persisted with the traditional educational approach, which positions the teacher in the center (Becker \& Riel, 1999).

Studies on change, learning and development amongst teachers note the need to understand their mental world as a pre-condition for applying change (Fullan, 2001). Teachers' readiness for ongoing independent learning and a sense of independent capability were found to positively influence the use of the computer in teaching (Marcinkiewicz, 1997). A revolution in the teachers' perceptions and beliefs is needed for meaningful educational change, since these have a crucial impact on applying change and on adopting innovation and its implementation (Fullan, 2001).

\subsubsection{The Influence of Teachers' Perceptions and Beliefs on Integrating Computer Technologies}

Teachers' credos therefore have considerable impact on the decision-taking process and on their methods of teaching and learning. According to Lamm (2001) education is activity guided by beliefs. The sources that feed the teachers' beliefs are values, the social framework of the teaching, and the expectations of the students, the system, parents and peers. The contention is that it is not possible to lead change in education without understanding the reciprocal relations between the teachers' credos and their teaching (Pajares, 1992).

There is frequently a connection between the term "perceptions" and the term "beliefs". In fact, the perceptions are structured according to, and based on, beliefs. The perceptions, as well as the beliefs, influence the decision-taking and the behavior (Richardson, 2003). Researchers differentiate between the teachers' knowledge and their beliefs (Kagan, 1992; Pajares, 1992). Exposure to knowledge, or even to the teachers' acquisition of knowledge, does not assure their choosing to believe in it and use it. Accordingly, the teachers' convictions have greater impact on their actions than their knowledge, and they predict behavior better.

Teachers' beliefs and perceptions affect their readiness to adopt change in teaching methods (Kagan, 1992; Pajares, 1992). The way of incorporating computer technology in the classroom and the extent of its integration are affected by the teachers' beliefs that the use of these technologies will help to improve their teaching and their professional development.

The chances of making use of ICT are increasing markedly amongst teachers who are discovering positive aspects of ICT and are familiar with its advantages. Studies show that teachers will exhibit more positive attitudes regarding the use of computers as their experience increases, will understand more the place of computers in their roles as teachers, and will be successful thanks to their assimilation in their lessons (Abbott \& Faris, 2001; Kay, 2006). According to Wertsch (1998) the use of a new tool leads to gradual change in thought; this change leads to the increased use of the tool, which again affects shaping thought. Hence experience using 
computers is likely to influence the change in teachers' perceptions and beliefs. Other researchers are convinced that the change in pedagogic perception precedes, and leads, assimilating the use of the tool. Thus, for example, teachers who espouse the constructivist approaches tend to use computer technologies and to integrate ICT in their teaching more than teachers who advocate more traditional beliefs - those who perceive the teacher as a key factor (Bai \& Ertmer, 2008; Matzen \& Edmunds, 2007). Such assumptions strengthen the claim that pedagogic training is needed to construct a constructivist approach to teaching.

Teachers' perceptions that are based on their beliefs enable predicting their behavior as regarding teaching, and understanding it (Richardson, 2003). Empirical studies note the connection between teachers, beliefs and perceptions and their behaviors (Calderhead, 1996; Clark \& Peterson, 1986; Pajares, 1992). Despite beliefs and thought being covert processes, while behavior is overt, there is a reciprocal relationship between them. The teachers' beliefs affect their perceptions and judgment, which in turn affect their decisions and methods of teaching in their classrooms.

At the same time, several researchers note the contradictions between the teachers' credos and their classroom behavior (Calderhead, 1996; Ertmer, Gopalakrishnan, \& Ross, 2001; Fang, 1996). Thus, for example, incompatibility was found between teachers' beliefs regarding computer technologies and their practical integration when teaching them: teachers who testified of themselves that they held a constructivist approach used the computer mainly for repetition and practice - only rarely did they employ it for challenging research assignments (Ertmer, Gopalakrishnan, \& Ross, 2001). Another study by Scott, Chovanec and Young, (1994) finds that the teachers expressed beliefs based on contradictory educational philosophies. Munby (1982) claims that the origin of the contradictions between teachers' perceptions and their practical teaching lies in additional deep beliefs held by them. These are of great weight in determining the teachers' behavior. Thus, for example, he avers that despite the teachers' beliefs that the most significant and correct use of computer technologies lies in investigative assignments, they use the computer mainly for practicing, due to their more fundamental credo that practice is an essential pre-condition for developing the students' skills.

These data emphasize the need to differentiate between diverse beliefs and to identify those that affect behavior. Such a differentiation will hone the understanding of the teachers' thought - thought that guides their activities and affects the extent of their success in assimilating changes. The considerable weight of perceptions and beliefs in determining the teachers' behavior, as well as their complex impact on applying changes in education, were the main motivation for conducting the study presented in this article. It aimed to explore the influence of teachers' beliefs on the place of computer technologies in teaching and on the teachers' professional functioning. The study focused on an examination of the perceptions of teachers experienced in integrating computers in teaching. According to Rogers (2003) the diffusion of innovation model knowledge precedes the development of the approach. Accordingly, the primary hypothesis was that teachers with knowledge and experience in integrating the computer in teaching will develop a coherent attitude to this subject.

\section{The Research Objective and Research Questions}

The main objective of this study was to examine the perception of teachers experienced in integrating computers in their work. To this end it was necessary to clarify whether they believe in the pedagogic advantages of computer technologies and how their perceptions affect the practical integration of computers in their work.

The following questions were derived from this objective:

1) What are the teachers' perceptions and beliefs regarding the integration of computer technologies in education?

2) What is the connection between the use of computer technologies and the teachers' perceptions?

\section{Methods}

\subsection{The Research Population}

The research population included 47 science teachers who teach in 38 elementary schools in southern Israel, all of whom are qualified to teach sciences in elementary schools.

Background data: All the teachers have four to twenty-five years of teaching experience, with an average seniority of nine years. All teach in elementary schools, and four of them also teach in junior high school. All the teachers have a computer at home connected to the internet. All of them have at least two computer stations in their classrooms connected to the internet; $72 \%$ of them have three to twelve computers in their classroom. All the teachers participated in training on the use of computer applications and their integration in teaching. The information on the subjects of their in-service training course on computer applications is presented in table 1, 
the running of most of which is the responsibility of the Ministry of Education. The courses on this subject include instruction and studying the diverse technological applications, as well as advanced applications such as integrating the internet in teaching, managing a class internet site, participating in ICT forums and so on.

Table 1. Teachers training courses on computer applications and their integration in teaching $(n=47)$

\begin{tabular}{lll}
\hline $\begin{array}{l}\text { No. of in-service training courses in the } \\
\text { last five years }\end{array}$ & $\begin{array}{l}\text { No. of } \\
\text { teachers }\end{array}$ & Proportion (\%) \\
\hline One & 4 & 9 \\
Two & 10 & 21 \\
Three or more & 33 & 70 \\
Last in-service training course & & \\
In the last year & 16 & 34 \\
3-2 years ago & 27 & 57 \\
3-5 years ago & 4 & 9 \\
No. of hours in last in-service training & & \\
course & 8 & 17 \\
Less than 56 hours & 26 & 55 \\
$56-112$ hours & 13 & 28 \\
More than 112 hours & & \\
Extent of integrating & computer & \\
applications in teaching & & \\
\%10Less than & 11 & 24 \\
\%50-30 & 33 & 70 \\
More than \%50 & 3 & 6 \\
\hline
\end{tabular}

As presented in table 1 most of the teachers (70\%) participated in at least three in-service training courses on computer applications and their integration in teaching. About $70 \%$ of the teachers reported that computer applications are integrated in their teaching in $30-50 \%$ of the time.

\subsection{The Research Tool}

The questionnaire included 31 closed questions (without the background questions) and two open questions. It had four parts (see appendix):

Part 1 of the questionnaire provided general background data: formal education in the world of teaching sciences, teaching seniority, the classes in which the teacher teaches, the number of computers in the science laboratory, whether the computers are connected to the internet, the number of in-service training courses the teacher attended in the last five years on the subject of computer applications and their integration in teaching, the number of hours in the last in-service training course, the times of the courses, and the extent of the integration of computers in teaching.

Part 2 of the questionnaire explored the extent of the integration of the computer in the teachers' work. It included nine statements (see appendix) that were evaluated by selecting one of four ranks on a Likert scale (totally disagree, agree somewhat, agree to a moderate degree, fully agree). The statements were selected after examining several questionnaires dealing with integrating computers in teaching and following consultation with two instructors of science teachers in the elementary schools. In addition, it included an open question that asked the teachers to describe a class teaching activity that integrated the use of a computer.

Part 3 of the questionnaire examined the teachers' attitudes and perceptions regarding the impact of integrating computers on their teaching, on the students for whom they are responsible, and on their professional advancement and status. This part included 21 statements that were evaluated by choosing one of four ranks on the Likert scale (totally disagree, agree somewhat, agree to a moderate degree, fully agree). The statements were selected after scrutiny of questionnaires that examine teachers' attitudes regarding integrating computers in 
teaching (Francis, Katz \& Jones, 2000; Gressard \& Loyd, 1986) and after consulting with two science teachers' instructors in elementary schools. The internal reliability of the questionnaire was $=0.90$. Factor analysis was conducted for all the 21 statements. In this analysis, three main dimensions were identified. The first dimensions included six statements dealing mainly with the teachers' status and professional advancement. The second dimension included eight statements pertaining to the advantages of integrating computers in teaching - their impact on active learning, partnership in learning and so on. The third dimension included five statements pertaining to teaching and learning without the integration of computers. The reliability of all three dimensions was high (Table 4).

Part 4 of the questionnaire included an open question regarding a statement that appears in part 3: If you agree with statement no. 2 in section 3 above ("Science teachers must be computer literate"), explain why this is so. Please note all the reasons that occur to you.

\subsection{Data Processing}

The percentage and frequency of the answers were calculated for the data obtained in the first part of the questionnaire. Averages, standard deviation and variance were calculated for the data from the second and third parts of the questionnaire. Factor analysis was conducted using the varimax method with orthogonal rotation for the teachers' attitudes that results in three dimensions, whose correlation was examined using Spearman's correlation. The open questions (in parts 2 and 4 of the questionnaire) were processed using content analysis. The answers to them were divided into main categories, and the frequencies and distributions were calculated as percentages for all the categories. The categories were established and determined according to the contents of the teachers' statements. The statements obtained in the response to the question, "Why do you think science teachers should be computer literate" were divided into five categories that present the factors given in reply to the question. The majority of the teachers noted more than three statements; most of which were assigned to the diverse categories, but some participants noted more than one statement in a particular category.

\section{Findings}

\subsection{Integrating Computer Applications in Teaching}

The results regarding the extent of integrating diverse computer applications in teaching are summarized in Table 2. They were divided into basic applications (using a word processor, searching for information on the internet and so on) and into advanced applications (participating in forums, managing a class internet site, and so on), as described in the introduction (Cuban, 2001). The findings clearly indicate that great use was made of the basic computer applications, but other applications were barely integrated in the teaching. Thus, for example, $57 \%$ of the teachers use a computer to a considerable extent to prepare work sheets and tests and about $70 \%$ of them seek lesson plans to a moderate or considerable extent on the internet. In contrast, only a small percentage of the teachers demand of their students to prepare assignments that necessitate the use of computer communications. Similarly, most (about 75\%) of the teachers lack a computer link with the students after school hours, and or participate in the computerized learning community. The last two items indicate that the teachers hardly use computers to maintain communications and professional cooperation beyond the school boundaries.

Table 2. Frequency of integrating computer applications

\begin{tabular}{|c|c|c|c|}
\hline Statement & Average & $\begin{array}{l}\text { Standard } \\
\text { deviation }\end{array}$ & $\begin{array}{l}\text { Proportion (\%) } \\
\text { of those } \\
\text { responding } \\
\text { "fully agree" }\end{array}$ \\
\hline \multicolumn{4}{|l|}{ Basic applications } \\
\hline Internet search for structured lesson plans & 3.68 & 0.78 & 30 \\
\hline Preparation of work sheets and tests using the computer & 3.30 & 0.88 & 57 \\
\hline $\begin{array}{l}\text { Use of closed computer learning programs for practice } \\
\text { during the lesson }\end{array}$ & 2.91 & 0.93 & 30 \\
\hline $\begin{array}{l}\text { Search for information on the Internet for planning } \\
\text { teaching units }\end{array}$ & 3.55 & 0.69 & 66 \\
\hline
\end{tabular}




\begin{tabular}{|c|c|c|c|}
\hline \multicolumn{4}{|l|}{ Advanced applications } \\
\hline Giving students assignments that demand the use of ICT & 2.17 & 0.98 & 15 \\
\hline Participation in a learning community using the internet & 1.30 & 0.59 & - \\
\hline ICT connection with students after school hours & 1.30 & 0.55 & - \\
\hline $\begin{array}{l}\text { Integrating simulations and computerized laboratories in } \\
\text { the lesson }\end{array}$ & 1.21 & 0.51 & - \\
\hline \multicolumn{4}{|l|}{ Other } \\
\hline $\begin{array}{l}\text { Technical problems are the main difficulty when } \\
\text { integrating computers in lessons }\end{array}$ & 1.19 & 0.85 & 4 \\
\hline
\end{tabular}

Most of the teachers claimed that the use of the computer does not entail many technological problems. Most of them disagreed with the statement, "Technical problems are the main difficulty when integrating computers in my lessons". This indicates that the technical skill is fairly good: in other words, other reasons influence the frequency of integrating computers in lessons.

\subsection{Description of Computer-Integrated Activities}

The answers to the open question, "Choose one activity in whose framework you integrated the use of computers in your teaching, and describe it" were somewhat surprising. The teachers were allowed to describe any type of activity, including such that they held once only. They were expected to choose to describe the most impressive activity they conducted, and therefore the preliminary assumption was that the frequency of the types of activity they would describe in the open question would not be similar to the frequency of the use of diverse computer applications presented in Table 2. However, the results received in the open answers differed only slightly, and in general, they supported the data presented in table 2. A total of 44 teachers answered the open question out of the sample of 47 teachers. The distribution of the answers according to their frequency is presented in Table 3 .

The data show that many teachers reported their use of computerized teaching programs (such as the materials that were developed by Israeli companies like "Lamda" or activities from the "Galim" site developed by "Snonit"), and integrated presentations in their teaching. Sixteen teachers claimed that they guided students in preparing investigative research work that incorporated the use of the computer; some of this work dealt with an integrative subject such as the environmental quality, in which framework the students were asked to find material on the internet and to write about diverse aspects of that topic. On the other hand, only a few teachers reported that they participated in an ICT project common to several schools, such as participating in the virtual science quiz of the Israel Center for Excellence in Education or in constructing a shared information pool. Only three teachers chose to describe the integration of simulations and computerized laboratories in their lessons.

These results and the results of the closed questionnaire (see Table 2) indicate the most partial assimilation of computers in lessons. Some learning situations changed qualitatively, but most computer applications that are used in teaching are basic.

Table 3. Analysis of the open question on the frequency of computer activities

\begin{tabular}{|c|c|c|}
\hline Type of activity & $\begin{array}{l}\text { Proportion of } \\
\text { teachers }(\%)\end{array}$ & No. of teachers \\
\hline Use of educational computer programs on science and technology & 36 & 16 \\
\hline Integrating multi-media presentations & 27 & 12 \\
\hline $\begin{array}{l}\text { Guiding students in research work or projects that integrate } \\
\text { computers }\end{array}$ & 16 & 7 \\
\hline Integrating computerized simulations and laboratories & 7 & 3 \\
\hline $\begin{array}{l}\text { Participation in computerized research projects common to several } \\
\text { schools }\end{array}$ & 7 & 3 \\
\hline An open or structured project combining internet surfing & 7 & 3 \\
\hline Total & 100 & 44 \\
\hline
\end{tabular}




\subsection{The Teachers' Attitudes regarding the Effect of Integrating Computers}

The teachers' attitudes, as a manifestation of their perception of the impact of integrating computers in their teaching, on the students and on their professional status are presented in table 4 below. According to the findings for the frequencies, all the teachers believed that science teachers must be computer literate and that their roles as such changed due to the integration of the computer in teaching. Most teachers also declared that they prefer to use the constructivist approach in their teaching, while integrating computers therein stems from pedagogic reasons more than from administrative reasons such as the demands of the Ministry of Education. More than $90 \%$ of the teachers agreed to a moderate or large extent that integrating computers in teaching helps their professional advancement. Broad agreement was also attained regarding the positive influence of teaching on the students when using a computer. Most teachers believed that the computer increases the degree of the students' interest, that students who use a computer are more active than those who do not integrate computers, and that the learning partnership between teacher and student when using a computer is greater than learning without assimilating computers. Furthermore, more than $90 \%$ of the teachers agreed that the use of a computer enriches investigative learning in sciences. Similar data were received regarding the teachers' agreement with the fact that, generally, integrated computer learning is more meaningful.

The results obtained from a summary of the teachers' attitudes towards teaching without a computer are interesting. In fact, most of the teachers agreed to a moderate or high degree with all the statements regarding teaching without a computer, similar to the broad agreement with statements that express the advantages of integrating computers in teaching. Most of the teachers believed that active learning occurs also without assimilating computers in teaching, that investigative learning occurs in science lessons even when teaching without a computer, and that skills dealing with developing thought also exist in lessons where no computer was used.

Statement no. 6 ("I prefer to follow the constructivist approach in teaching") was not ascribed to any of the dimensions, but it is important to emphasize it as all the participants agreed with this statement that emphasizes the teachers' declared perception of (average 3.51).

Examination of the correlation between the three dimensions (see Table 5) finds a highly significant positive correlation between "The teacher's status and his professional advancement" and "The advantages of integrating computers in teaching". A distinct negative coefficient was found between "The teachers' status and their professional advancement" and "Teaching and learning without a computer". These distinct statistical connections are likely to indicate that teachers believe that those who integrate computer applications in their teaching enjoy a more prestigious status amongst their students and amongst their colleagues, and are rewarded by their professional advancement. In contrast, no distinct statistical connection was found between "Teaching and learning without a computer" and "The advantages of integrating computers in learning". The absence of a statistical connection between these two dimensions indicates that most of the teachers who agree that there are advantages to assimilating computers in teaching (advancing active teaching and research, improving learning partnerships and developing more meaningful learning) agree that teaching without a computer also advances active learning, research and developing thought. 
Table 4. Teachers' attitudes regarding the impact of computers in their teaching

\begin{tabular}{|c|c|c|c|c|c|c|c|}
\hline \multirow[t]{2}{*}{ Dimension } & \multirow{2}{*}{$\begin{array}{l}\text { No. of statements } \\
\text { included in } \\
\text { dimension }\end{array}$} & \multicolumn{3}{|c|}{$\begin{array}{l}\text { Average and standard deviation } \\
\text { for each statement }\end{array}$} & \multirow[t]{2}{*}{$\begin{array}{l}\text { Dimension } \\
\text { Ave. }\end{array}$} & \multirow[t]{2}{*}{ S.D } & \multirow[t]{2}{*}{$\alpha$} \\
\hline & & Statement no. & Ave. & S.D. & & & \\
\hline \multirow{6}{*}{$\begin{array}{l}\text { Teacher's status } \\
\text { and professional } \\
\text { advancement }\end{array}$} & \multirow[t]{6}{*}{6} & 1 & 3.40 & 0.61 & \multirow[t]{6}{*}{3.43} & \multirow[t]{6}{*}{0.55} & \multirow[t]{6}{*}{0.75} \\
\hline & & 2 & 3.74 & 0.44 & & & \\
\hline & & 3 & 3.53 & 0.62 & & & \\
\hline & & 4 & 3.49 & 0.66 & & & \\
\hline & & 5 & 3.79 & 0.41 & & & \\
\hline & & 7 & 2.66 & 0.58 & & & \\
\hline \multirow{8}{*}{$\begin{array}{l}\text { The advantages of } \\
\text { integrating } \\
\text { computers in } \\
\text { teaching }\end{array}$} & \multirow[t]{8}{*}{8} & 8 & 1.83 & 0.92 & \multirow[t]{8}{*}{2.83} & \multirow[t]{8}{*}{0.78} & \multirow[t]{8}{*}{0.79} \\
\hline & & 9 & 2.09 & 0.83 & & & \\
\hline & & 12 & 3.30 & 0.78 & & & \\
\hline & & 13 & 2.98 & 0.79 & & & \\
\hline & & 14 & 3.21 & 0.72 & & & \\
\hline & & 16 & 3.04 & 0.75 & & & \\
\hline & & 17 & 3.43 & 0.65 & & & \\
\hline & & 18 & 2.77 & 0.86 & & & \\
\hline \multirow{5}{*}{$\begin{array}{l}\text { Teaching and } \\
\text { learning without a } \\
\text { computer }\end{array}$} & \multirow[t]{5}{*}{5} & 10 & 2.62 & 0.74 & \multirow[t]{5}{*}{3.16} & \multirow[t]{5}{*}{0.66} & \multirow[t]{5}{*}{0.79} \\
\hline & & 15 & 3.30 & 0.83 & & & \\
\hline & & 19 & 3.15 & 0.72 & & & \\
\hline & & 20 & 3.28 & 0.74 & & & \\
\hline & & 21 & 3.45 & 0.65 & & & \\
\hline
\end{tabular}

Statements no. 6: (average: 3.51 ) and 11 (average: 2.46) did not belong to any of the dimensions.

*Statement content appears in the appendix at the end of the article.

Table 5. Correlation between the teachers' attitudes regarding the impact of integrating computers

\begin{tabular}{lllll}
\hline Dimension & & $\begin{array}{l}\text { Teacher's status } \\
\text { and professional } \\
\text { advancement }\end{array}$ & $\begin{array}{l}\text { Advantages of } \\
\text { integrating the } \\
\text { computer in teaching }\end{array}$ & $\begin{array}{l}\text { Teaching and } \\
\text { learning without } \\
\text { a computer }\end{array}$ \\
\hline $\begin{array}{l}\text { Teacher's status and } \\
\text { professional }\end{array}$ & $\begin{array}{l}\text { Coefficient } \\
\text { advancement }\end{array}$ & - & $.686\left(^{* *}\right)$ & $-.383\left(^{* *}\right)$ \\
$\begin{array}{l}\text { Advantages of } \\
\text { integrating the } \\
\text { computer in teaching }\end{array}$ & $\begin{array}{l}\text { Coefficient } \\
\text { Teaching and }\end{array}$ & $.686\left(^{* *}\right)$ & -000 & .008 \\
$\begin{array}{l}\text { Significance } \\
\text { compung without a }\end{array}$ & .000 & - & -.188 \\
\hline
\end{tabular}

** Level of significance of the correlation was smaller than 0.01 (two-tailed)

\subsection{Why Must the Science Teacher Be Computer Literate?}

In reply to the question, "Why must the science teacher be computer literate?" 148 statements were received. It is important to emphasize that teachers were expected to answer the question only if they agreed with statement no. 2: "A science teacher must be computer literate". The statements were divided into five categories reflecting the main factors noted by the respondents to the question. The categories, the frequency of the statement in each category and their distribution in percentages are summarized in Table 6. Furthermore, table 6 presents the percentage of teachers who noted the category and its frequency, as well as selected quotations from the teachers' replies. 
Most of the teachers $(81.8 \%)$ noted aspects pertaining to advancing the teaching as reasons for determining that the science teacher must be computer literate. This category included 92 statements (about $62 \%$ of all the statements), including repeated terms such as "teaching is more tangible", "experiential teaching" "diversity" "challenge", and "active teaching". Repeat statements also appeared in the category pertaining to promoting learning. Twenty-one teachers of the 44 teachers noted aspects pertaining to this category (a total of 35 statements were included), and used terms such as "meaningful learning", "investigative learning", "independent learning", "independent experience", "learning tools", and so on. A few teachers noted professional and personal advancement, and a few mentioned other factors such as strengthening the connection with the students or the school management's demand (see Table 6). The significant disparity in the number of statements between the categories of advancing teaching and advancing learning, and the other categories indicates that most of the teachers perceive the computer as a tool whose main importance lies in its educational ability to improve teaching and learning.

Table 6. Classification of the responses to the question, "Why must the science teacher be computer literate?"

\begin{tabular}{|c|c|c|c|}
\hline Category & $\begin{array}{l}\text { *No. of } \\
\text { statements (\%) } \\
\mathrm{N}=148\end{array}$ & $\begin{array}{l}* * \text { No. of } \\
\text { teachers }(\%) \\
\mathrm{N}=44\end{array}$ & Selected quotations from the teachers' responses \\
\hline $\begin{array}{l}\text { Advancing } \\
\text { the teaching }\end{array}$ & $\begin{array}{l}92 \\
(\% 62.2)\end{array}$ & $\begin{array}{l}36 \\
(\% 81.8)\end{array}$ & $\begin{array}{l}\text { Teaching using a computer is more tangible"; } \\
\text { "Lessons with a computer are more fun and } \\
\text { interesting"; "The lessons with a computer are more } \\
\text { structured and more comprehensible"; "There are } \\
\text { countless activities on the internet, such , for } \\
\text { example, as the virtual laboratories that vary the } \\
\text { lessons"; "The computer is essential for active and } \\
\text { challenging teaching, it is an endless source of ideas } \\
\text { for activities" }\end{array}$ \\
\hline $\begin{array}{l}\text { Advancing } \\
\text { the learning }\end{array}$ & $\begin{array}{l}35 \\
(\% 23.6)\end{array}$ & $\begin{array}{l}21 \\
(\% 47.8)\end{array}$ & $\begin{array}{l}\text { "The computer empowers the student's meaningful } \\
\text { learning through independent experimentation with } \\
\text { diverse activities"; "The students prefer to learn } \\
\text { with the computers and are more involved in } \\
\text { learning"; "The richness of the activities on the } \\
\text { computer facilitates independent learning by the } \\
\text { students (mainly those having difficulties), } \\
\text { stimulates and arouses them to study and research"; } \\
\text { "The computer is a tool for furthering personal } \\
\text { learning ". }\end{array}$ \\
\hline $\begin{array}{l}\text { Personal and } \\
\text { professional } \\
\text { advancement }\end{array}$ & $\begin{array}{l}21 \\
(\% 14.2)\end{array}$ & $\begin{array}{l}8 \\
(\% 18.2)\end{array}$ & $\begin{array}{l}\text { "The computer is an enormous source of knowledge } \\
\text { that enables being updated constantly". "Teachers } \\
\text { who fear the computer remain behind, deny } \\
\text { themselves a professional step forward, must adopt } \\
\text { computers". "I am not only a science teacher but for } \\
\text { sciences and technology. It is a professional } \\
\text { necessity". "The computer is a basic work tool". }\end{array}$ \\
\hline $\begin{array}{l}\text { Connection } \\
\text { to the } \\
\text { students }\end{array}$ & $\begin{array}{l}7 \\
(\% 4.7)\end{array}$ & $\begin{array}{l}5 \\
(\% 11.4)\end{array}$ & $\begin{array}{l}\text { "The computer is the center of the students' lives. } \\
\text { In order to be close to the students one must be } \\
\text { familiar with their world". "The computer } \\
\text { strengthens my connection to the students, even } \\
\text { with the shy ones". }\end{array}$ \\
\hline $\begin{array}{l}\text { Demands of } \\
\text { the system }\end{array}$ & $\begin{array}{l}3 \\
(\% 2.1)\end{array}$ & $\begin{array}{l}3 \\
(\% 6.8)\end{array}$ & $\begin{array}{l}\text { "Science and technology teachers must master the } \\
\text { computer and integrate it in their lessons". "The } \\
\text { principal pushes all the teachers to participate in } \\
\text { training as to how to integrate the computer". }\end{array}$ \\
\hline
\end{tabular}

* The column expresses the number of statements in each category. Their proportion out of a total of 148 statements appears in parenthesis.

** The column expresses the number of teachers who noted the category. Their proportion out of a total of 44 teachers who noted this category appears in parenthesis. 


\section{Discussion}

The study described in this article explores the perceptions of experienced teachers of using a computer in their teaching. The research hypothesis was based on the teachers' experience, and hence was that their perceptions regarding integrating computers in the education system would be positive. As described in the professional literature, experience is likely to influence the development of a positive perception (Abbott \& Faris, 2000; Kay, 2006).

The findings indicate that, on the one hand, the teachers manifest positive attitudes towards integrating computers in the education system. All the teachers who participated in the study declared that this altered their roles as teachers and affected their professional status. Most of them also believed that computer technologies have a significant impact on advancing teaching and on advancing learning. The majority also declared that the use of computers is important for advancing teaching, and following the assimilation of computers in lessons there was a change in their teaching approach and its organization.

On the other hand, it would seem that usually the teachers use basic computer applications (such as computer learning programs and the search for information on the internet) and hardly integrate in teaching the use of advanced computer applications (such as computerized laboratories or the use of computers as an interactive tool). Although in this study most teachers declared that they prefer to teach using the constructivist approach, they did not adopt ICT technologies that further this approach. These data are similar to those of other studies and indicate the disparity between the teachers' declarations and their classroom activities (Calderhead, 1996; Ertmer, Gopalakrishnan, \& Ross, 2001; Fang, 1996). It would seem that the teachers who participated in the current study mainly adopted the technological applications that assure the traditional method of teaching, rather than those likely to alter it. These results are compatible with Cuban's (2001) findings, which showed that many teachers believe that the computer helps the students' activities mainly as enrichment rather then as a key activity. According to Ertmer (1999) teachers tend to view the computer as a tool auxiliary to teaching that is mainly used for data and information processing; they perceive the internet as pool of information rather than as a provider of communications.

There is therefore a contradiction between the teachers' positive attitudes vis-à-vis computer technology and their but partial use of these technologies. This contradiction may perhaps be explained based on the research findings regarding the teachers' attitudes on teaching without a computer. Many of the teachers believe that active learning, investigative learning and developing thought skills will exist largely also without integrating computers in teaching. There is no doubt that active learning can be conducted and thought developed also without a computer. But these attitudes of the teachers, together with the limited use made of advanced computer applications, reveal that their perception is different from that declared: the teachers do not believe in the significant advantages of ICT technologies.

The findings suggest that technical problems are not the reason for the teachers hardly integrating advanced computer applications in their teaching. The only partial assimilation of computer technologies stems from the rooted belief amongst teachers, according to which meaningful learning is also feasible without using advanced computer applications. Therefore, there is no point in integrating computers in teaching.

It is not clear to what extent the teachers are aware of the contradiction between their declared perception (i.e. the importance of integrating computer technologies in teaching and their educational implications) and the reverse perception that is manifested in their practice. This paradox may create dilemmas for them, but it would seem that they have found a way to contain these contradictions and make them congruent with their beliefs. The teachers who integrate computers in their lessons to a not inconsiderable extent see this as a crucial matter, as well as an important factor that helps to advance their status and raise their professional prestige (see Tables 4 and 5). At the same time, they actually integrate only the basic computer applications that sustain their traditional educational credo (see Tables 2 and 3).

The teachers thus have a network of perceptions and beliefs. Some of them block the full use of technology and some encourage its maintenance. The perception that the use of computers will raise the teachers' professional prestige motivates them to integrate computers in teaching, while the position that the computer is not essential to their work leads them to use basic applications that do not alter their role. Furthermore, all the teachers who participated in this study declared that they integrate the computer in their teaching in a significant manner, such that led to change in their roles and in their teaching approach. One should assume, accordingly, that from their point of view the change is not needed by them at all. A change in perceptions will only occur if a strong need awakens in them for such change and it will cause them to replace an old approach with a new one. As long as the teachers talk in post-modern terms, declare that a change occurred in their roles and in their teaching methods, 
and claim that they are teaching using the constructivist approach, the need for change will not awaken in them. The network of contradictory beliefs preserves the traditional educational approach, inhibits the development of a constructivist educational approach and blocks the full assimilation of computer technologies.

The contradictions emphasize the need for profound clarification of the teachers' perceptions, since these are the main factor influencing the assimilation of computer technologies. Cuban (2001) asserts that in most reforms in the world of education, and especially in the reform calling for integrating computers in school, serious consideration of the teachers' perceptions was lacking. According to him, this is one of the reasons for the failure of one of the most expensive reforms instituted in the education system.

It is difficult to alter deep-rooted perceptions and beliefs, and to cope with change is complex and multi-dimensional (Levin \& Wadmany, 2005). In this framework there is no way to discuss these methods of coping, but only to stress possible directions. Thus, for example, an intense examination is demanded of the teachers' training program, in order to try to focus on the educational rationale. One of the assertions is that the teachers hardly integrate communications technologies in their classrooms, due, mainly, to the lack of clear pedagogic rationale. Educational objectives with which the teachers identify, and an agreed pedagogic rationale, are an essential basis for the development of an educational approach (Papert, 1998; Voogt \& Pelgrum, 2005). Accordingly, the training programs should consider the teachers' beliefs and perceptions, encourage them to reveal them and help them to develop alternative credos. Similarly, the focus should be on shaping the perceptions of new and of pre-service teachers. Amongst the generation that grew up with computers it may be easier to advance this approach that sees computer technologies as a lever for a different pedagogy. Researchers note that it is possible to predict the approach of pre-service teachers regarding computer technologies according to the beliefs of the teachers themselves (Bai \& Ertmer, 2008). It is therefore important to focus also on developing the educational approach of teachers' teachers, who afford a role model for the students. These educators are likely to advance positive perceptions and belief in the pedagogic potential of the technology amongst the new teachers, and this may well lead to more significant assimilation of computer technology.

Although the teacher population that participated in the study was quite small, the participants were teachers most experienced in the use of computers and their integration in the class. The exposure, in this study, of inhibiting beliefs, as well as the contradictions amongst teachers experienced in the use of computers in their teaching, indicates that the technological skills and experience using computers do not necessarily further the credo of the importance of integrating computers, and do not lead to significant assimilation from the pedagogic perspective. It is important to introduce a constraint here and to state that it is not clear to what extent the findings of this study can be applied to experienced teachers from other areas, or to all the teachers working in diverse cultural communities. It would, however, seem that the findings presented in this article emphasize the universal complexity of the teachers' perceptions and the difficulty in their understanding.

As noted, most of the findings in this study that pertain to integrating computers in teaching, confirm, findings from other studies. However, the uniqueness of this work lies in revealing contradictions in the teachers' perceptions of which they are apparently unaware. These contradictions make their readiness to integrate computers in their teaching difficult.

A further study that will examine the teachers' personal interpretations of their dual positions will cause them to face their rooted beliefs and will offer reflective thought, likely to help to create deeper understanding of their attitudes. Such understanding will advance their coping with the need for change in perspective and will motivate the assimilation of computer technologies in the education system.

\section{References}

Abbott, J. A., \& Faris, S. E. (2001). Integrating technology into preservice literacy instruction: A survey of elementary education students' attitudes toward computers. Journal of Research on Computing in Education, 33(2), 149-161.

Bai, H., \& Ertmer, P. A. (2008). Teacher educators' beliefs and technology uses as predictors of preservice teachers' beliefs and technology attitudes. Journal of Technology and Teacher Education, 16(1), 93-112.

Becker, H. J. (1994). How exemplary computer-using teachers differ from other teachers: Implications for realizing the potential of computers in schools. Journal of Research on Computing in Education, 26(3), 291-321.

Becker, H. J., \& Riel, M. M. (1999, September). Teacher professionalism and the emergence of constructivist-compatible pedagogies. Paper presented at the meeting of the American Educational 
Research Association, Montreal, Canada. Retrieved July 8, 2013, from http://www.crito.uci.edu/tlc/findings/special_report2/aerj-final.pdf

Calderhead, J. (1996). Teachers: Beliefs and knowledge. In D. C. Berliner, \& R. C. Calfee (Eds.), Handbook of educational psychology (pp. 709-725). New York: Macmillan.

Clark, C. M., \& Peterson, P. L. (1986). Teachers' thought processes. In M. C. Wittrock (Ed.), Handbook of research on teaching (3rd ed., pp. 255-296). New York: Macmillan.

Cuban, L. (2001). Oversold and underused: Computers in the classroom. Cambridge, MA: Harvard University Press.

Ertmer, P. A. (1999). Addressing first- and second-order barriers to change: Strategies for technology integration. Educational Technology Research and Development, 47(4), 47-61. http://dx.doi.org/10.1007/BF02299597

Ertmer, P. A. (2005). Teacher pedagogical beliefs: The final frontier in our quest for technology integration? Educational Technology Research and Development, 53(4), 25-39. http://dx.doi.org/10.1007/BF02504683

Ertmer, P. A., Gopalakrishnan, S., \& Ross, E. M. (2001). Technology-using teachers: Comparing perceptions of exemplary technology use to best practice. Journal of Research on Computing in Education, 33(5), 1-27. Retrieved July 8, 2013, from http://www.edci.purdue.edu/ertmer/docs/AERA_2000.pdf

Fang, Z. (1996). A review of research on teacher beliefs and practices. Educational Research, 38(1), 47-65. http://dx.doi.org/10.1080/0013188960380104

Francis, L. J., Katz, Y. J., \& Jones, S. H. (2000). The reliability and validity of the Hebrew version of the Computer Attitude Scale. Computers \& Education, 35(2), 149-159. http://dx.doi.org/10.1016/S0360-1315(00)00022-1

Franklin, C. A. (2007). Factors that influence elementary teachers' use of computers. Journal of Technology and Teacher Education, 15(2), 267-293.

Fullan, M. G. (1998). Leadership for the $21^{\text {st }}$ century: Breaking the bonds of dependency. Educational Leadership, 55(7), 6-10.

Fullan, M. G. (2001). The new meaning of educational change (3rd ed.). New York: Teachers College Press.

Gressard, C. P., \& Loyd, B. H. (1986). Validation studies of a new computer attitude scale. Association for Educational Data Systems Journal, 18(4), 295-301.

Hills, V. (2010). The 2010 CDW-G $21^{\text {st }}$-century classroom report: Preparing students for the future or the past? Retrieved July 8, 2013, from http://webobjects.cdw.com/webobjects/media/pdf/newsroom/CDWG-21stCentury-Classroom-Report-0610.pdf

Kagan, D. M. (1992). Implications of research on teacher belief. Educational Psychologist, 27(1), 65-90. http://dx.doi.org/10.1207/s15326985ep2701_6

Kay, R. H. (2006). Evaluating strategies used to incorporate technology into preservice education: A review of the literature. Journal of Research on Technology in Education, 38(4), 383-408. http://dx.doi.org/10.1080/15391523

Lamm, Z. (2001). Preamble to the discussion of the problem of teacher training theory. Dapim, 32, 132-150.

Levin, T., \& Wadmany, R. (2005). Changes in educational beliefs and classroom practices of teachers and students in rich technology-based classrooms. Technology, Pedagogy and Education, 14(3), 281-307. http://dx.doi.org/10.1080/14759390500200208

Marcinkiewicz, H. R. (1997). Will teachers use educational computing technology? In Z. L. Berge, \& M. P. Collins (Eds.), Wired together: The online classroom in K-12, 3 (pp. 109-119). Cresskill, NJ: Hampton Press.

Matzen, N. J., \& Edmunds, J. A. (2007). Technology as a catalyst for change: The role of professional development. Journal of Research on Technology in Education, 39(4), 417-430. http://dx.doi.org/10.1080/15391523.2007.10782490

Mouza, C. (2003). Learning to teach with new technology: Implications for professional development. Journal for Research on Technology in Education, 272-289. http://dx.doi.org/10.1080/15391523.2002.10782386 
Munby, H. (1982). The place of teachers' beliefs in research on teacher thinking and decision making, and an alternative methodology. Instructional Science, 11, 201-225. http://dx.doi.org/10.1007/BF00414280

Pajares, M. F. (1992). Teachers' beliefs and educational research: Cleaning up a messy construct. Review of Educational Research, 62(3), 307-332. http://dx.doi.org/10.3102/00346543062003307

Palak, D., \& Walls, R. T. (2009). Teachers' beliefs and technology practices: A mixed-methods approach. Journal of Research on Technology in Education, 41(4), 417-441. http://dx.doi.org/10.1080/15391523.2009.10782537

Papert, S. (1998). Child power: Keys to the new learning of the digital century. Retrieved July 8, 2013, from http://www.papert.org/articles/Childpower.html

Pelgrum, W. J., \& Anderson, R. E. (Eds.). (1999). ICT and the emerging paradigm for life long learning: A worldwide educational assessment of infrastructure, goals, and practices. Enschede, the Netherlands: University of Twente.

Pelgrum, W. J. (2001). Obstacles to the integration of ICT in education: Result from a worldwide educational assessment. Computers \&Education, 37, 163-178. http://dx.doi.org/10.1016/S0360-1315(01)00045-8

Richardson, V. (2003). Preservice teachers' beliefs. Advances in Teacher Education, 6, 1-22.

Rogers, E. M. (2003). Diffusion of innovation (5th ed.). New York: Free Press.

Salomon, G. (1996). Studying the computer vs. the whole learning environment: Relating analytic and systemic paradigms. In S. Strauss (Ed.), Development and learning environments. New York: Ablex.

Sandholtz, J. H., Ringstaff, C., \& Dwyer, D. (1997). Teaching with technology: Creating student-centered classrooms. New York: Teachers College Press.

Scott, S. M., Chovanec, D. M., \& Young, B. (1994). Philosophy-in-action in university teaching. The Canadian Journal of Higher Education, 24(3), 1-25.

Venezky, R. L., \& Davis, C. (2002). Ouo Vademus? The transformation of schooling in a networked world. Paris: OECD. Retrieved July 8, 2013, from http://www.oecd.org/LongAbstract/0,2546,fr_2649_ 201185_2073047_1_1_1_1,00.html

Voogt, J., \& Pelgrum H. (2005). ICT and curriculum change. Human Technology, 1(2), 157-175.

Wellington, J. (2005). Has ICT come of age? Recurring debates on the role of ICT in Education, 1982-2004.

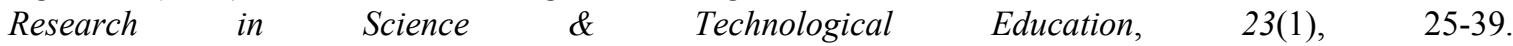
http://dx.doi.org/10.1080/02635140500068419

Wertsch, J. V. (1998). Mind as action. New York: Oxford University Press.

\section{Appendix}

\section{Questionnaire for science and technology teachers in elementary schools}

A. General information

- Do you have a teaching certificate for the sciences (Please circle your reply) Yes No

- Hoe many years have you been teaching in elementary school?

- In which classes do you teach? (Please circle the appropriate classes)

$$
\begin{array}{lllllllll}
1 & 2 & 3 & 4 & 5 & 6 & 7 & 8 & 9
\end{array}
$$

- How many computers re there in the science laboratory

- Are the computers connected to the Internet?

- In how many in-service training courses on the subject of the use of the computer and its integration in teaching have you participated in the last five years?
a) None
b) One
c) Two
d) Three
e) More than three

- When did the last in-service training course take place?

- How many hours had the last course in which you participated?
a) Up to 56 hours
b) 56-112 hours
c) More than 112 hours 
B. Rank the degree of your agreement with each of the following statements.

The fourth level (of four levels) of assessment: 1.Totally disagree; 2 . Agree somewhat; 3 . agree to a moderate degree; 4.Fully agree.

\begin{tabular}{|l|l|l|l|l|l|}
\hline No. & Statement & 1 & 2 & 3 & 4 \\
\hline 1 & I am seeking information on the computer to prepare a lesson. & & & & \\
\hline 2 & I use the computer to prepare work sheets and tests. & & & & \\
\hline 3 & $\begin{array}{l}\text { I use closed computer learning programs for practice in the } \\
\text { lesson. }\end{array}$ & & & & \\
\hline 4 & $\begin{array}{l}\text { In the lesson I combine teaching with open computer learning } \\
\text { programs. }\end{array}$ & & & & \\
\hline 5 & I seek information on the computer to plan a teaching unit. & & & & \\
\hline 6 & $\begin{array}{l}\text { I give assignments that demand finding information on the } \\
\text { internet. }\end{array}$ & & & & \\
\hline 7 & $\begin{array}{l}\text { I participate in a learning community through the internet. } \\
\text { There is an ICT connection between myself and my students } \\
\text { after the teaching hours. }\end{array}$ & & & & \\
\hline 9 & $\begin{array}{l}\text { Technical problems are my main difficulty when integrating the } \\
\text { computer in teaching. }\end{array}$ & & & & \\
\hline 10 & $\begin{array}{l}\text { I conduct computerized simulation as an alternative to } \\
\text { traditional laboratories. }\end{array}$ & & & & \\
\hline
\end{tabular}

Select one activity in the framework of which you integrated the use of computers in your teaching and describe it.

C. Rank the degree of your agreement with each of the following statements:

1. Totally disagree; 2 . Agree somewhat; 3 . Agree to a moderate degree; 4. Fully agree

\begin{tabular}{|c|c|c|c|c|c|}
\hline No. & Statement & 1 & 2 & 3 & 4 \\
\hline 1 & $\begin{array}{l}\text { Teaching combined with the computer contributes to advancing the } \\
\text { profession. }\end{array}$ & & & & \\
\hline 2 & A science teacher must be computer literate. & & & & \\
\hline 3 & $\begin{array}{l}\text { The status of a teacher who integrates the use of the computer in his } \\
\text { lessons is considered higher by his students than a teacher who does } \\
\text { not integrate the use of computers in his lessons. }\end{array}$ & & & & \\
\hline 4 & $\begin{array}{l}\text { The status of a teacher who integrates computers in his lessons is } \\
\text { considered higher by the principal and the teaching staff than that of a } \\
\text { teacher who does not integrate the use of a computer in his lessons. }\end{array}$ & & & & \\
\hline 5 & $\begin{array}{l}\text { The role of a science teacher has changed following the integration of } \\
\text { computers in teaching. }\end{array}$ & & & & \\
\hline 6 & I prefer to teach according to the constructivist approach. & & & & \\
\hline 7 & $\begin{array}{l}\text { My teaching plan is determined according to the extent of my ability } \\
\text { to integrate the use of computers. }\end{array}$ & & & & \\
\hline 8 & $\begin{array}{l}\text { I integrate the use of computers in lessons following the standards } \\
\text { determined by the Ministry of Education. }\end{array}$ & & & & \\
\hline 9 & $\begin{array}{l}\text { I combine the use of computers in lessons, since the school is } \\
\text { committed to a particular program. }\end{array}$ & & & & \\
\hline 10 & Integrating the computer causes a waste of time. & & & & \\
\hline
\end{tabular}




\begin{tabular}{|l|l|l|l|l|l|}
\hline 11 & $\begin{array}{l}\text { Seeking information on the internet exposes the students to } \\
\text { problematic sources. }\end{array}$ & & & & \\
\hline 12 & $\begin{array}{l}\text { Integrating the computer affects the degree of the students' interest in } \\
\text { the lesson. }\end{array}$ & & & & \\
\hline 13 & The learner who integrates the computer is a more active learner. & & & \\
\hline 14 & $\begin{array}{l}\text { The teacher-student learning partnership is greater when the } \\
\text { computer is integrated. }\end{array}$ & & & & \\
\hline 15 & $\begin{array}{l}\text { I taught using the research approach prior to integrating the use of the } \\
\text { computer in the lesson. }\end{array}$ & & & & \\
\hline 16 & Computer-integrated teaching leads to more meaningful learning. & & & & \\
\hline 17 & The computer leads to enriched learning how to study sciences. & & & & \\
\hline 18 & Active learning exists in every lesson that integrates the computer. & & & & \\
\hline 19 & $\begin{array}{l}\text { Investigative learning in science lessons exists even without } \\
\text { integrating the computer. }\end{array}$ & & & & \\
\hline 20 & Active learning exists even without integrating computers. & & & \\
\hline 21 & $\begin{array}{l}\text { Skills of developing thought exist in lessons that do not integrate } \\
\text { computers. }\end{array}$ & & & & \\
\hline
\end{tabular}

D. If you agree with statement no. 2 in section $\mathrm{C}$ above, explain why the science teacher must be computer literate. Please note all the reasons that occur to you.

\section{Copyrights}

Copyright for this article is retained by the author(s), with first publication rights granted to the journal.

This is an open-access article distributed under the terms and conditions of the Creative Commons Attribution license (http://creativecommons.org/licenses/by/3.0/). 